\title{
Properties of Foamed Lightweight High-Performance Phosphogypsum-Based Ternary System Binder
}

\author{
Girts Bumanis * ${ }^{\mathbb{D}}$, Jelizaveta Zorica and Diana Bajare \\ Department of Building Materials and Products, Riga Technical University, LV-1658 Riga, Latvia; \\ jelizaveta.zorica@rtu.lv (J.Z.); diana.bajare@rtu.lv (D.B.) \\ * Correspondence: girts.bumanis@rtu.lv; Tel.: +371-26062011
}

Received: 21 August 2020; Accepted: 4 September 2020; Published: 8 September 2020

check for updates

Featured Application: This research brings introduction to a novel type of hydraulic binder based on phosphogypsum. Ternary system binder based on phosphogypsum, Portland cement, and pozzolan was elaborated as high-performance material with the strength up to $90 \mathrm{MPa}$. This binder is characterized by low Portland cement content and low water-binder ratio. Mineralogical and microstructural investigation was performed and data represented. Furthermore, development of lightweight foamed concrete based on developed binder was created using foaming agents.

\begin{abstract}
The potential of phosphogypsum (PG) as secondary raw material in construction industry is high if compared to other raw materials from the point of view of availability, total energy consumption, and $\mathrm{CO}_{2}$ emissions created during material processing. This work investigates a green hydraulic ternary system binder based on waste phosphogypsum (PG) for the development of sustainable high-performance construction materials. Moreover, a simple, reproducible, and low-cost manufacture is followed by reaching PG utilization up to $50 \mathrm{wt} . \%$ of the binder. Commercial gypsum plaster was used for comparison. High-performance binder was obtained and on a basis of it foamed lightweight material was developed. Low water-binder ratio mixture compositions were prepared. Binder paste, mortar, and foamed binder were used for sample preparation. Chemical, mineralogical composition and performance of the binder were evaluated. Results indicate that the used waste may be successfully employed to produce high-performance binder pastes and even mortars with a compression strength up to $90 \mathrm{MPa}$. With the use of foaming agent, lightweight $\left(370-700 \mathrm{~kg} / \mathrm{m}^{3}\right)$ foam concrete was produced with a thermal conductivity from 0.086 to $0.153 \mathrm{~W} / \mathrm{mK}$. Water tightness (softening coefficient) of such foamed material was 0.5-0.64. Proposed approach represents a viable solution to reduce the environmental footprint associated with waste disposal.
\end{abstract}

Keywords: phosphogypsum; ternary binder; high performance; strength; foam; lightweight material; thermal conductivity

\section{Introduction}

Gypsum binder is widely used in construction due to its ease of production, availability, and low price [1]. Physically, gypsum is infinitely recyclable; however, the recycling process requires additional energy [2]. Despite these benefits, the disadvantage of gypsum binder is its brittleness, poor resistance to cracking, and unsuitability for damp conditions. Traditional gypsum binder use has been defined in EN 12859, where the main gypsum application is associated with the production of plasters, blocks, tiles, and boards [3]. Besides natural gypsum, synthetic gypsum, produced as chemical by-product, is used widely for the production of gypsum products. There are more than 50 different types of gypsum waste [2]. However, the most common by-product is phosphogypsum (PG), flue gas desulphurization gypsum, and borogypsum $[4,5]$. Phosphogypsum (PG) is produced as a by-product 
from phosphate fertilizer production and the annual PG production reaches $280 \mathrm{mlj} . \mathrm{t}$ worldwide and only about $15 \%$ of PG is used as secondary raw material, but rest is disposed in open-type stacks [5]. Partially or completely, synthetic gypsum can be a substitute for natural gypsum as cement admixtures, gypsum-based plasters, drywalls. Researches on production of traditional gypsum binders based on PG are widely published, but they have rather limited practical application due to specific nature of PG [6]. Moreover, there are legislation limits and prejudice coming from society regarding PG, so the direct use of PG as substitution of natural gypsum is problematic. More complicated and effective way of the utilization of PG is to create an advanced and new type of binder, which has a much lower carbon footprint comparing to Portland cement, while remaining strength properties similar to Portland cement. It was reported that the addition of blast furnace slag and cement could effectively improve the mechanical strength of PG. However, fly ash played a negative role on the compressive strength of PG [7]. S. Kumar described properties of fly ash-lime-phosphogypsum ternary binder [8] or recently anhydrous gypsum was used to develop lime-pozzolan green binder [9]. Two waste-stream materials were used and only lime was defined as a primary resource, the calcination temperature $\left(900-1100{ }^{\circ} \mathrm{C}\right)$ of latter is lower compared to Portland cement. In this case, the amount of PG in the binder was in the range from $10-40 \%$. However, the disadvantage comparing to Portland cement is low compressive strength-which could be in range from 2-4 MPa [8]; nevertheless it is reasonable if it is compared to the lime binder and hydraulic lime binder. Higher strength results were obtained in ternary binder system phosphogypsum-steel slag-granulated blast-furnace slag (GGBS)-limestone cement, where the content of PG was from $25-65 \%$, while the amount of slag was from $22-48 \%$. The obtained strength at the age of 28 days was up to $45 \mathrm{MPa}$ while the obtained binder is characterized with fast setting time (initial setting time 6-9 $\mathrm{min}$, final 10-12 $\mathrm{min}$ ) [10]. These results are more comparable to traditional binders, while the problem could be a fast setting time. The fast setting may not benefit the engineering application because there is not enough time for casting before the cement sets. In some case it was reported that the citric acid in amount from $0.03-0.15 \mathrm{wt} . \%$ of cement could retard setting time significantly. The use of citric acid could increase the open time from 25 to $47 \mathrm{~min}$, while this admixture tended to slightly reduce compressive strength of the binder [11]. In ternary systems where Portland cement is present, superplasticizer can be used and low water-binder ratio can be achieved. Traditionally, supplementary materials that are utilized to replace ordinary Portland cement decrease the workability of the cementitious mixtures and superplasticizers such as polycarboxylate based are usually added to cement to control their fluidity [12]. The use of polycarboxylate acid-based superplasticizer could be used from $0.75-1.75 \mathrm{wt} . \%$; however, reports say that it could slightly reduce early compressive strength of the material while final strength tended to increase [11]. These aspects regarding to the utilization of PG in new types of binders were considered in present research by choosing mixture composition, including use of chemical admixtures.

To continue the development of alternative waste stream binders in a production of new materials and enhance its valorization possibilities, novel lightweight foam material based on developed ternary binder was elaborated. In construction industry, there is growing interest in lightweight concretes. It combines positive properties of constructive and insulation materials and is characterized by moderate strength, low density, and improved thermal properties. Cellular concrete is composed on mortar matrix and specially created system of air cells, which occupies up to $85 \%$ of material volume [13]. High porosity limits potential of mechanical strength, but high volume of open pores is the main reason for increased water absorption and drying shrinkage. The density of traditional gypsum ranges from 600 to $1500 \mathrm{~kg} / \mathrm{m}^{3}$, as given in Clause 4.8.1. of EN 12859 [3]. This well-known standard covers the gypsum application range, and beyond this range, research is being conducted to make gypsum material more sustainable. Attempts to produce lightweight gypsum with foaming admixtures have yielded a material with density ranging from 300 to $600 \mathrm{~kg} / \mathrm{m}^{3}$ [14]. Such material has low density, superior sound, and thermal insulation and can be considered a sustainable high-performance material. High-efficiency sound-absorbing material was made also with PG, which composite structure was described by Baoguo Ma et al. [15]. Thus, aim of the work was to produce in laboratory conditions 
lightweight ternary system based material with density less than $600 \mathrm{~kg} / \mathrm{m}^{3}$, which is outside the traditional boundaries to bring the novelty of the research. Bulk density and thermal conductivity were set as target values, which should be determined together with technological properties so that gypsum material could be easily produced and handled (workability, strength). Here, research on development of highly porous ternary system gypsum-based binder material was evaluated and compared.

\section{Materials and Methods}

Dihydrate phosphogypsum $\left(\mathrm{CaSO}_{4} \cdot 2 \mathrm{H}_{2} \mathrm{O}\right)$ analyzed in this work is a waste generated by fertilizer production plant AB Lifosa (Kèdainiai, Lithuania) in wet-process phosphoric acid production, where apatite from the Kovdor mine, Kola peninsula, Russia, is decomposed by sulphuric acid. To produce $1 \mathrm{t}$ of orthophosphoric acid, about 3.0-4.5 $\mathrm{t}$ of PG is obtained [16]. At the enterprise, volcanic origin Cola apatite (Kirov and Kovdor) (containing $\mathrm{F}_{2} 1-2 \%, \mathrm{P}_{2} \mathrm{O}_{5}$-about $38 \%$ as phosphorus) is used as a raw material in the production of phosphoric acid. Besides, phosphorites of sedimentary origin from other countries (Morocco, Jordan, Kazakhstan (Karatau), Algeria, South Africa Republic) are used. The dihydrate PG was used as secondary raw material in the present research. Chemical composition of raw materials is given in Table 1. The initial pH of PG is in the range from 2.2-2.9 while during the storage it can increase gradually. The PG was dried at $60{ }^{\circ} \mathrm{C}$ (moisture content $9-12 \mathrm{wt} . \%$ ) and milled to powder-like particles with collision milling in semi-industrial disintegrator with the rotational speed of $50 \mathrm{~Hz}$. The particle size distribution is given in Figure 1. Then, the calcium sulfate hemihydrate binder was obtained by treatment of milled gypsum powder at temperature $180^{\circ} \mathrm{C}$ for $4 \mathrm{~h}$. Commercial gypsum plaster (BG) was used to compare the characteristic technological properties of obtained binder.

Table 1. Chemical composition of raw materials used to prepare novel building material [weight \%].

\begin{tabular}{ccccc}
\hline Element & Commercial Gypsum BG & Phosphogypsum PG & Metakaolin MKW & Cement CEM I 42.5N \\
\hline $\mathrm{SiO}_{2}$ & 3.73 & 1.07 & 51.80 & 22.64 \\
$\mathrm{Al}_{2} \mathrm{O}_{3}$ & 1.68 & 0.70 & 34.20 & 5.93 \\
$\mathrm{Fe}_{2} \mathrm{O}_{3}$ & 0.46 & 0.22 & 0.50 & 3.26 \\
$\mathrm{CaO}$ & 35.64 & 37.16 & 0.10 & 57.04 \\
$\mathrm{MgO}$ & 3.92 & 0.21 & 0.10 & 4.26 \\
$\mathrm{SO}_{3}$ & 30.90 & 37.38 & - & 3.30 \\
$\mathrm{Na}_{2} \mathrm{O}$ & 0.31 & 0.48 & 0.60 & 0.10 \\
$\mathrm{~K}_{2} \mathrm{O}$ & - & - & - & 2.40 \\
$\mathrm{TiO}_{2}$ & 0.05 & 0.11 & 0.60 & 0.38 \\
$\mathrm{Cl}$ & - & - & - & 0.14 \\
$\mathrm{P}_{2} \mathrm{O}_{5}$ & - & 0.57 & - & 0.46 \\
$\mathrm{LOI}$ & 22.43 & 19.24 & 11.5 & - \\
$\mathrm{Total}$ & 99.42 & 99.74 & 99.60 & 99.90 \\
\hline
\end{tabular}

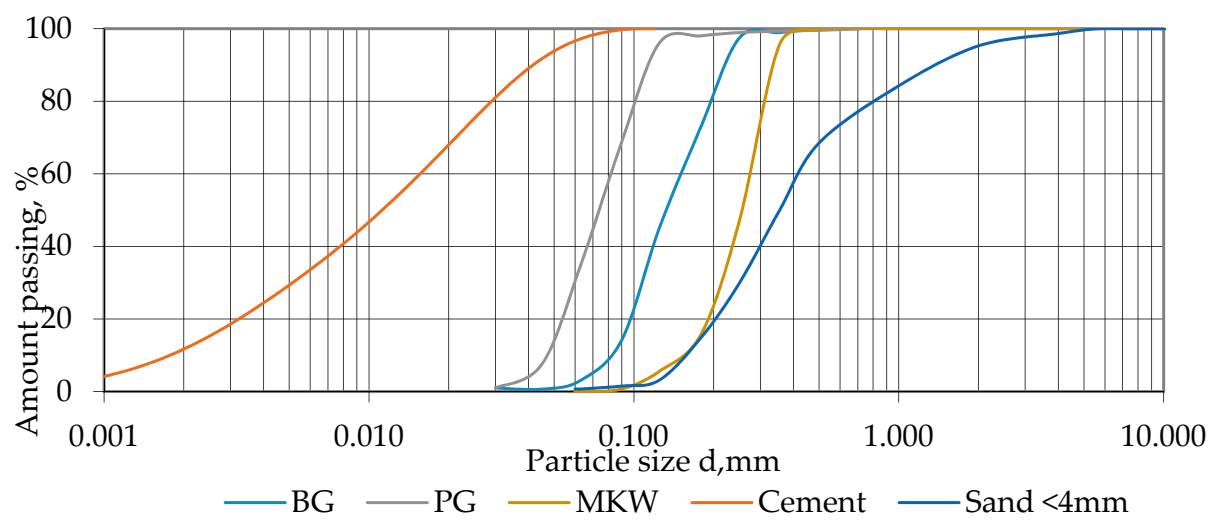

Figure 1. The particle size distribution of the raw materials used to prepare novel building material. 
The other components of the binder were metakaolin as supplementary cementitious material and Portland cement CEM I 42.5N (CEM). Chemical composition of CEM is given in Table 1. The initial setting time was $182 \mathrm{~min}$ and the final setting was $224 \mathrm{~min}$ (according to LVS EN 196-3); the normal consistency was $28.2 \%$ (according to LVS EN 196-3). Blaine fineness of cement was $3787 \mathrm{~cm}^{2} / \mathrm{g}$ (according to LVS EN 196-6). Na equivalent was 1.68. Compressive strength after 1 day was $15.4 \mathrm{MPa}$, after 2 days-32.9 MPa, after 7 days-48.8 MPa, and after 28 days-60.5 MPa. Waste metakaolin (MKW) was obtained from the porous glass granule production factory "Stikloporas" JSC (Druskininkai, Lithuania). Metakaolin is a by-product from the final stage of expanded glass granule production, where kaolinite clay powder is used as a substance for anti-agglomeration and is heated at $850{ }^{\circ} \mathrm{C}$ temperature for 40-50 min. MKW is mostly amorphous dehydration product of kaolinite, $\mathrm{Al}_{2}(\mathrm{OH})_{4} \mathrm{Si}_{2} \mathrm{O}_{5}$, which exhibits strong pozzolanic activity often used in the concrete industry as a supplementary cementitious material. XRD pattern and detailed description of MKW was published before [17]. MKW contains amorphous metakaolin detected in $2 \theta$ region from 15 to $30^{\circ}$, and some minor crystalline phases were also detected in MKW: quartz $\left(\mathrm{SiO}_{2}\right)$ and Halloysite $\mathrm{Al}_{2} \mathrm{Si}_{2} \mathrm{O}_{5}(\mathrm{OH})_{4}$. The specific surface area of the $\mathrm{MKW}$ is $15.86 \mathrm{~m}^{2} / \mathrm{g}$. Loss of ignition for metakaolin was $11.5 \%$. The particle size distribution of materials used in the preparation of ternary binder is given in Figure 1.

Sika ViscoCrete G-2 is a high-performance superplasticizer/water reducer based on polycarboxylate (PCE) polymer technology. PCE is formulated for applications in systems with high calcium sulfate content or pure gypsum-based binders. Gips RETARD (TKK) is a powdered citric acid-based admixture, which was used for regulating the setting time of gypsum. Gips RETARD was added to the dry binder mixture and mixed thoroughly before water was added. Sodium dodecyl sulfate (SDS) $\geq 85 \%$, pure (Acros Organics), was used as foam stabilizer for preparation of foamed samples. To produce porous, lightweight ternary system material, anion surface-active substance with stabilizing and functional agents PB-Lux was used.

Prepared mixture composition is given in Table 2. First two compositions were ternary system binder pastes (GCP-PG and GCP-BG). The difference between two of them is that in one case, commercial gypsum binder is used (abbreviation with BG), while in the other one PG binder is used (abbreviation with PG). The amount of PCE was 1.5\% from the total amount of binder while set retarder $\mathrm{R}$ was $0.2 \%$. Set retarder was used for samples with $\mathrm{PG}$ as it has a shorter set time comparing to commercial gypsum [6]. The W/B ratio was 0.34 for both mixtures. Other two mixtures were based on two mentioned binder pastes, but additional washed quartz sand $(0 / 4 \mathrm{~mm})$ was incorporated into the mixture composition with binder-sand ratio 1:1.75. The W/B ratio slightly increased with the incorporation of sand.

Table 2. Mixture composition of prepared ternary system binder paste and ternary system binder mortar.

\begin{tabular}{ccccccccc}
\hline Mixture & PG & BG & CEM & MKW & G-2 & R & Sand 0/4 mm & W/B \\
\hline GCP-PG & 1 & & 0.4 & 0.4 & $1.5 \%$ & $0.2 \%$ & - & 0.34 \\
GCP-BG & & \multirow{2}{*}{1} & 0.4 & 0.4 & $1.5 \%$ & - & - & 0.34 \\
GCP-PG-S & 1 & & 0.4 & 0.4 & $1.5 \%$ & 0.2 & 1.75 & 0.36 \\
GCP-BG-S & & 1 & 0.4 & 0.4 & $1.5 \%$ & - & 1.75 & 0.36 \\
\hline
\end{tabular}

Mixing procedure of binder pastes was similar to traditional cement mortars. First, dry components including set retarder were homogenized for $2 \mathrm{~min}$. Then, powder gradually was added into the water and superplasticizer mixture and homogenized for $2 \mathrm{~min}$ before casting. Mortar was mixed similar to the pastes, while the sand and extra water were added to the pre-mixed paste. Samples were cast in $20 \times 20 \times 20 \mathrm{~mm}$ or $40 \times 40 \times 160 \mathrm{~mm}$ molds for further testing.

The mixture composition of foamed ternary system binder is given in Table 3. Four mixture compositions were prepared. The amount of foam that was prepared was similar for all mixture compositions. The amount of binder paste homogenized with foams was changed for both compositions. SDS stabilizing admixture was used during the preparation of foams. Mixing procedure of binder 
pastes was similar to traditional cement mortars. First, dry components including set retarder were homogenized for $2 \mathrm{~min}$. Then, powder gradually was added into the water and superplasticizer mixture and homogenized for 2 min before introduction in simultaneously prepared foams. Then, binder paste was cast in foams and homogenized for $3 \mathrm{~min}$. Both commercial gypsum BG and phosphogypsum PG was compared. Plate samples with dimensions $35 \times 35 \times 5 \mathrm{~cm}$ were prepared for thermal conductivity measurements. Samples were further cut to cubical specimens $5 \times 5 \times 5 \mathrm{~cm}$ and physical properties as well as mechanical properties were tested.

Table 3. Mixture compositions of foamed ternary system binder.

\begin{tabular}{ccccccccccc}
\hline \multirow{2}{*}{ Composition } & \multicolumn{10}{c}{ Components, Weights Parts } \\
\cline { 2 - 11 } & Water, Foams & Water, Binder & PG & BG & PBLUX & CEMII & MKW & R & G-2 & SDS \\
\hline GCP-PG-1 & 200 & 410 & 750 & - & 5 & 312 & 312 & 2.5 & 21 & 2.5 \\
GCP-PG-2 & 200 & 560 & 1050 & - & 5 & 437 & 437 & 3.5 & 29.5 & 3.5 \\
GCP-BG-1 & 200 & 370 & - & 750 & 5 & 312 & 312 & 2.5 & 21 & 2.5 \\
GCP-BG-1 & 200 & 520 & - & 1050 & 5 & 437 & 437 & 3.5 & 29.5 & 3.5 \\
\hline
\end{tabular}

The setting time of the obtained binder was tested using the Vicat apparatus. Consistency of fresh mortar was tested with the Suttard's viscometer. Early age $(24 \mathrm{~h})$ and $28 \mathrm{~d}$ compressive strength was determined. After $24 \mathrm{~h}$, samples were cured in moist conditions (RH 95\%). At the age of $35 \mathrm{~d}$, air dry samples were tested. Samples with dimension of $20 \times 20 \times 20 \mathrm{~mm}$ were tested using Zwick Z100 with testing speed of $0.5 \mathrm{~mm} / \mathrm{min}$. The specific gravity and total porosity were determined by using Le Chatelier flask. Hardened samples were ground to powder with planetary ball mill Retch PM400 for $10 \mathrm{~min}$ with a speed of $300 \mathrm{rpm}$, and obtained powder was used to determine specific gravity. Total porosity was calculated from bulk density and specific gravity. Water absorption was measured for prismatic specimens for binder and mortar $(40 \times 40 \times 160 \mathrm{~mm})$ and cubical specimens for porous samples $(50 \times 50 \times 50 \mathrm{~mm})$. Samples were dried at $60^{\circ} \mathrm{C}$ until a constant mass was obtained, then samples were immersed in water for $72 \mathrm{~h}$ and saturated mass was obtained. Then, water absorption was calculated and open porosity determined using the volumetric measurements of individual samples. The mineralogical composition was determined by X-ray diffraction (XRD) (PAN analytical X'Pert $\mathrm{PRO}$ ). The macrostructure of the material was observed by a digital microscope at a magnification of 40 and 120x. Scanning Electron Microscopy (SEM) with Energy Dispersive Spectroscopy (EDX) was used (JEOL JSM 820 + IXRF systems 500 digital processing, Japan) for microscopic analysis of binder paste with $20 \mathrm{kV}$ voltage. The thermal conductivity of the materials was determined using the LaserComp heat meter FOX600, according to the guidelines of Standard LVS EN 12667. Foamed ternary system binder plate specimens with dimensions of $35 \times 35 \times 5 \mathrm{~cm}$ were prepared for thermal conductivity test. Temperature difference between testing plates was $20^{\circ} \mathrm{C}$ (the bottom plate was $+20^{\circ} \mathrm{C}$ and the upper plate was $0^{\circ} \mathrm{C}$ ).

\section{Results and Discussion}

Results are represented in two main subsections where dense ternary system binder properties are described (Section 3.1) and in Section 3.2 where properties of lightweight ternary binder are represented.

\subsection{Properties of High-Performance Ternary System Binder and Mortar}

The ternary system binder was described through its appearance in macro and micro level, chemical and mineralogical composition through hydration processes. Fresh and hardened properties of the binder and mortar were determined and results represented.

\subsubsection{Appearance of Ternary System Binder and Mortar}

The macrostructure of GCP-PG mortar is given in Figure 2. The difference between binder depending on the gypsum type used (PG or BG) did not influence the appearance of the macrostructure 
of the material. Mortar has a homogenous structure where individual sand filler grains and the binder can be identified. As $50 \mathrm{wt} . \%$ of the binder is gypsum, the material has a white appearance that is characteristic for gypsum binders. The whitish appearance could be an advantage for the creation of exposed architectural or structural elements. Small black inclusions as remains of foam glass granules originated from waste metakaolin were indicated, which could be a negative factor influencing the strength of the binder and mortar.

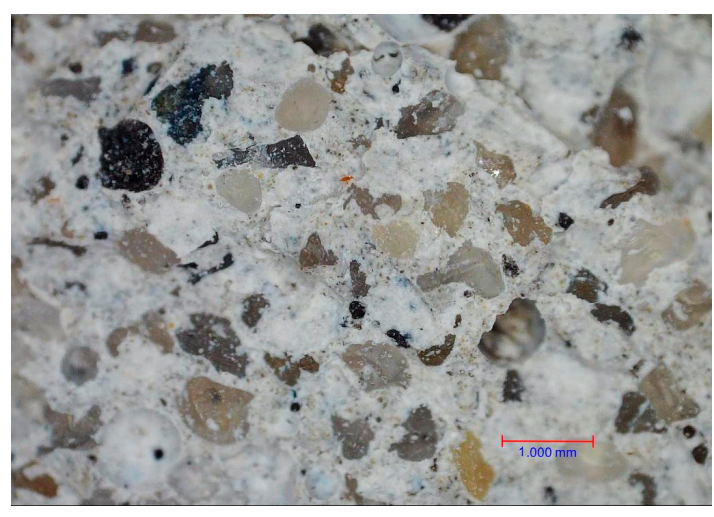

(a)

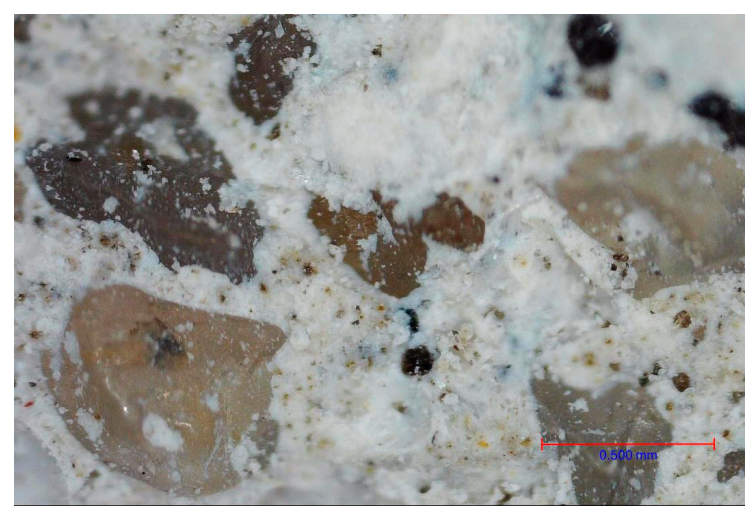

(b)

Figure 2. Macrostructure of ternary system mortar (a) under magnification of 40x, (b) under magnification of $120 x$.

The microstructure of the ternary binder (GCP-PG and GCP-BG) is given in Figure 3. It has a complex fine-grained structure with a large monolithic structure in smaller magnification (500x). The magnification at 2000x reveals the interaction between binder components and different regions, which can be identified.

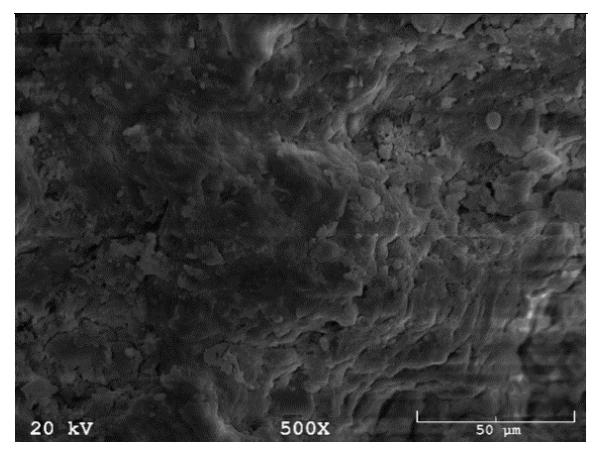

(a)

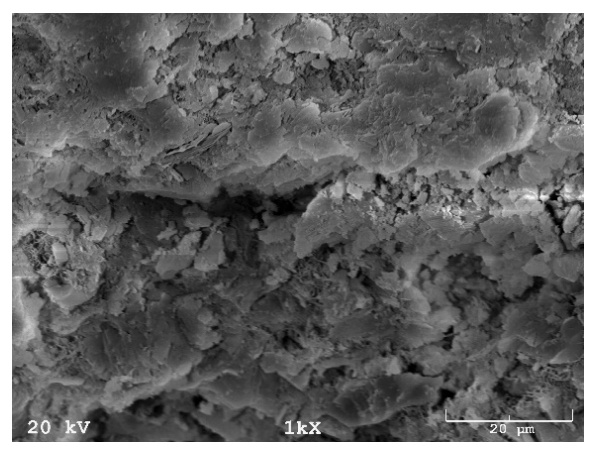

(c)

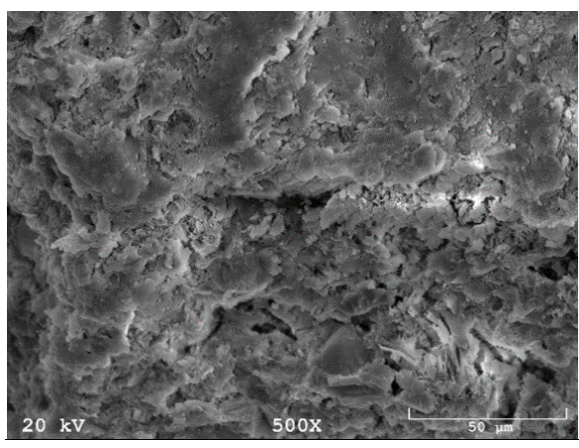

(b)

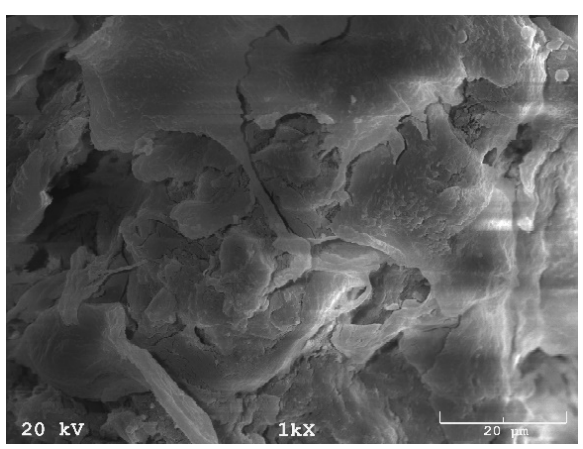

(d)

Figure 3. Microstructure of the ternary binder detected by SEM in magnification of 500x and 1000x. (a,c) GCP-phosphogypsum (PG), (b,d) GCP-BG. 


\subsubsection{Chemical and Mineralogical Characterization}

XRD results are given in Figure 4. The mineralogical composition of a ternary binder powder was investigated before hydration (Figure $4 \mathrm{c}, \mathrm{d})$. Bassanite $\left(\mathrm{CaSO}_{4} \cdot 0.5 \mathrm{H}_{2} \mathrm{O}\right.$, ref $\left.33-0310\right)$, calcium silicate oxide $\left(\mathrm{Ca}_{3}\left(\mathrm{SiO}_{4}\right) \mathrm{O}\right.$, ref 73-0599), and quartz $\left(\mathrm{SiO}_{2}\right.$, ref 78-1252) were identified from the source dry materials of GCP-PG. GCP-BG had the same three minerals as for GCP-PG, while additionally a dolomite $\left(\mathrm{CaMg}\left(\mathrm{CO}_{3}\right)_{2}\right.$, ref 36-0426) and an anhydrite $\mathrm{Ca}\left(\mathrm{SO}_{4}\right)$, ref $\left.72-0916\right)$ were also detected, which is associated with the composition of commercial BG.
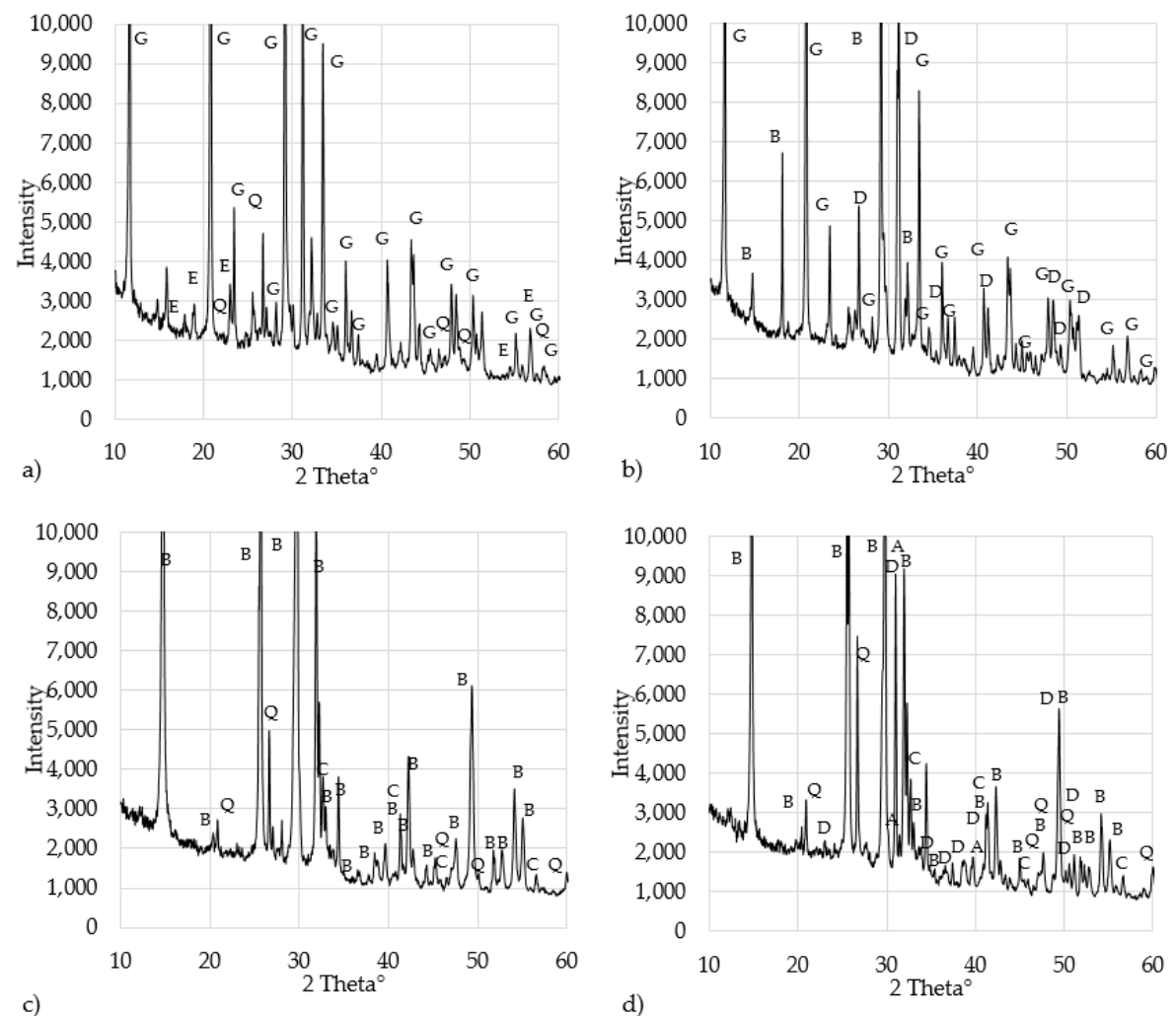

Figure 4. Mineralogical characterization of raw material mixture and hydrated paste of ternary binder: (a) Hydrated GCP-PG; (b) hydrated GCP-BG, (c) raw mixture of GCP-PG, (d) raw mixture of GCP-BG. B-Bassanite $\left(\mathrm{CaSO}_{4} \cdot 0.5 \mathrm{H}_{2} \mathrm{O}\right.$, ref 33-0310), $\mathrm{C}$ - calcium silicate oxide $\left(\mathrm{Ca}_{3}\left(\mathrm{SiO}_{4}\right) \mathrm{O}\right.$, ref 73-0599), $\mathrm{Q}$-quartz $\left(\mathrm{SiO}_{2}\right.$, ref 78-1252), D-dolomite $\left(\mathrm{CaMg}\left(\mathrm{CO}_{3}\right)_{2}\right.$, ref 36-0426), A-anhydrite $\mathrm{Ca}\left(\mathrm{SO}_{4}\right)$, ref 72-0916), G-gypsum $\left(\mathrm{Ca}\left(\mathrm{SO}_{4}\right)\left(\mathrm{H}_{2} \mathrm{O}\right)_{2}(74-1433)\right.$, E-ettringite $\left(\mathrm{Ca}_{6}\left(\mathrm{Al}(\mathrm{OH})_{6}\right)_{2}\left(\mathrm{SO}_{4}\right)_{3}\left(\mathrm{H}_{2} \mathrm{O}\right)_{26}\right.$, ref 72-0646).

The phase change after binder hydration was detected (Figure 4a,b). Moreover, ternary binder contained gypsum, cement, and pozzolan, the only phases which were identified in a hydrated GCP-PG mixture where gypsum $\left(\mathrm{Ca}\left(\mathrm{SO}_{4}\right)\left(\mathrm{H}_{2} \mathrm{O}\right)_{2}\right.$ (74-1433), quartz $\left(\mathrm{SiO}_{2}\right.$, ref 78-1252), and ettringite $\left(\mathrm{Ca}_{6}\left(\mathrm{Al}(\mathrm{OH})_{6}\right)_{2}\left(\mathrm{SO}_{4}\right)_{3}\left(\mathrm{H}_{2} \mathrm{O}\right)_{26}\right.$, ref 72-0646) were present. The formation and presence of the ettringite in such a late hydration stage are associated with high gypsum content in the mixture. In such a way, expansions can occur from excessive calcium sulfoaluminate formation after hardening and continue until the gypsum becomes depleted, that is why pozzolan was added and, according to previous studies, addition of pozzolan could even eliminate delayed ettringite formation [18]. In mixture composition, GCP-BG ettringite was not detected. Besides minerals coming from raw materials (dolomite, quartz), gypsum $\left(\mathrm{Ca}\left(\mathrm{SO}_{4}\right)\left(\mathrm{H}_{2} \mathrm{O}\right)_{2}\right.$ (74-1433) and also gypsum hemihydrate $\mathrm{Ca}\left(\mathrm{SO}_{4}\right)\left(\mathrm{H}_{2} \mathrm{O}\right)_{0.5}$ were detected, which could be formed slowly from the hydration of the anhydrite.

The EDX analysis of the GCP-PG binder is given in Figure 5. Large amount of Ca element was identified in most EDX points analyzed, which is associated with the fact that $\mathrm{Ca}$ is present in all binder 
components (phosphogypsum, cement, and metakaolin). The gypsum source in the structure can be identified through element $\mathrm{S}$, which comes from PG binder $\left(\mathrm{CaSO}_{4} 0.5 \mathrm{H}_{2} \mathrm{O}\right)$. Small quantities of $\mathrm{Al}$ and $\mathrm{Si}$ were identified as elements coming from metakaolin and cement. This explains the fact that no cement minerals were identified by XRD. The XRD analysis of raw material mixture and hardened binder was investigated while no strong new mineralogical peaks were identified. Mostly transition between gypsum hemihydrate and gypsum dihydrate was observed.

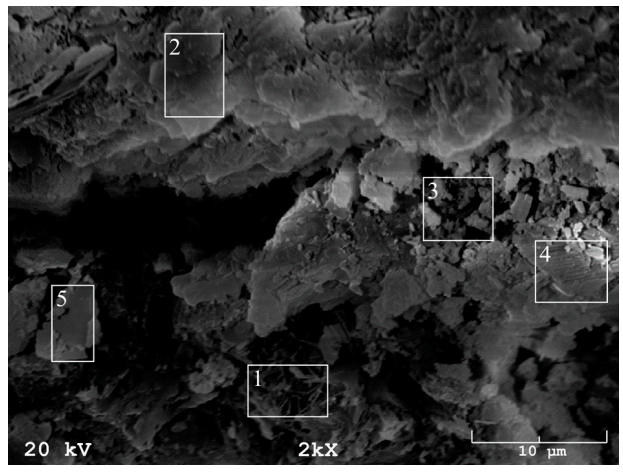

(a)

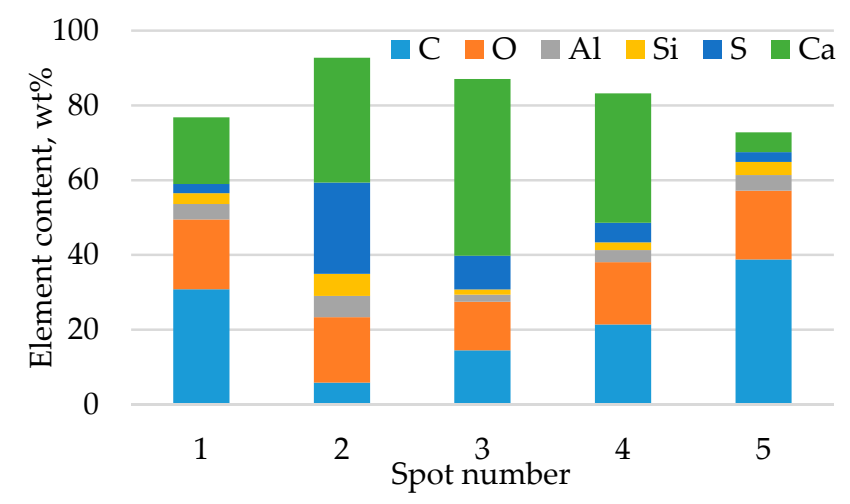

(b)

Figure 5. Energy Dispersive Spectroscopy (EDX) analysis of GCP-PG binder. (a) point positions analyzed by EDX, (b) element content in analyzed region.

\subsubsection{Physical and Mechanical Properties}

The bulk density of hardened binder is given in Table 4 . The density of binder paste GCP-BG is slightly lower comparing to GCP-PG (1609 to $\left.1766 \mathrm{~kg} / \mathrm{m}^{3}\right)$, which can be explained by the finer particle distribution for PG and denser structure of the paste. Similar tendencies were observed for mortar. The bulk density of a mortar material increased to 1886 and $2027 \mathrm{~kg} / \mathrm{m}^{3}$ for GCP-BG-S and GCP-PG-S, respectively. The total porosity for GCP-PG and GCP-BG was 23 and 29 vol.\%, while for mortar it was even lower -11 and 17 vol. $\%$ for GCP-PG-S and GCP-BG-S. The low porosity is associated with low $\mathrm{W} / \mathrm{B}$ ratio, which is also similar to traditional concrete nature [19]. This phenomenon had an influence also on the compressive strength of the materials presented.

Table 4. Physical properties of high-performance ternary system binder.

\begin{tabular}{cccccc}
\hline \multirow{2}{*}{ Mixture } & $\begin{array}{c}\text { Consistency by Suttard } \\
\text { Viscosimeter, } \mathbf{m m}\end{array}$ & \multicolumn{2}{c}{ Setting Time, min } & Dry Density, & $\begin{array}{c}\text { Total Porosity, } \\
\text { vol. } \%\end{array}$ \\
\cline { 3 - 4 } & Initial & Final & & vol. \\
\hline GCP-PG & 370 & 165 & 280 & $1766 \pm 9$ & $23 \pm 2.2$ \\
GCP-PG-S & 230 & 130 & 170 & $2027 \pm 14$ & $11 \pm 1.2$ \\
GCP-BG & 295 & 70 & 130 & $1609 \pm 24$ & $29 \pm 2.4$ \\
GCP-BG-S & 210 & 75 & 85 & $1886 \pm 38$ & $17 \pm 1.9$ \\
\hline
\end{tabular}

The consistency of fresh material was strongly affected by the amount of superplasticizer and low water content. The initial mixing of binder powder with water and plasticizer gives stiff mixture while during the intensive mixing, the effect of superplasticizer takes place and very viscous mixture was obtained with flow diameter $-295 \mathrm{~mm}$ for GCP-BG and $370 \mathrm{~mm}$ for GCP-PG. The low W/B ratio of the paste (GCP-PG and GCP-BG) gives similar consistency as for ultra-high performance concrete [20]. The flow for GCP-PG was higher, which is associated with the finer particle nature of PG. The prepared mortar was less viscous comparing to paste while the effect of superplasticizer was also present and high workability obtained. The flow of mortar was from $210-230 \mathrm{~mm}$.

The setting time was longer for GCP-PG and GCP-PG-S as set retarder was purposely used in mixture composition. The initial setting time was from 130-165 min for binder paste and mortar. 
The final set time was longer for GCP-PG (280 $\mathrm{min}$ ) than for mortar GCP-PG-S (170 $\mathrm{min}$ ) as it was more viscous to initiate the set of the paste. GCP-BG and GCP-BG-S initial setting time was slightly influenced by the mineral additives ( $\mathrm{t}_{\mathrm{in}} 70$ and $75 \mathrm{~min}$, respectively), while the final set time was longer for GCP-BG (130 $\mathrm{min}$ ) and was reduced for mortar GCP-BG-S (85 min).

The compressive strength results are given in Figure 6 . The compressive strength increased during the water curing similar as for Portland cement binder. The strength after demolding at $24 \mathrm{~h}$ was similar among all samples (13-15 MPa). The further curing resulted in slower strength gain for mortars (GCP-PG-S and GCP-BG-S). At the age of $28 \mathrm{~d}$, the strength of moist samples reached $50 \mathrm{MPa}$ for GCP-PG and $30 \mathrm{MPa}$ for GCP-BG. The strength increase was not observed between 7 and $28 \mathrm{~d}$ for GCP-BG. The mortar strength reached $26 \mathrm{MPa}$ for GCP-BG-S and $43 \mathrm{MPa}$ for GCP-PG-S. After sample drying, material strength increased significantly at the age of $35 \mathrm{~d}$. The GCP-PG reached $88 \mathrm{MPa}$ while GCP-PG-S mortar reached $50 \mathrm{MPa}$. Binder GCP-BG had $49 \mathrm{MPa}$ and mortar GCP-BG-S had $39 \mathrm{MPa}$, respectively. The failure of the mortar was mostly in the transition zone of aggregate and binder. Such result is highly competitive and promising compared to traditional Portland cement mortars. The higher strength results obtained for materials based on PG could be explained by the fine nature of PG giving more reactive nature for ternary binder. Moreover, commercial gypsum BG could contain other additives that could lead to lower strength results.

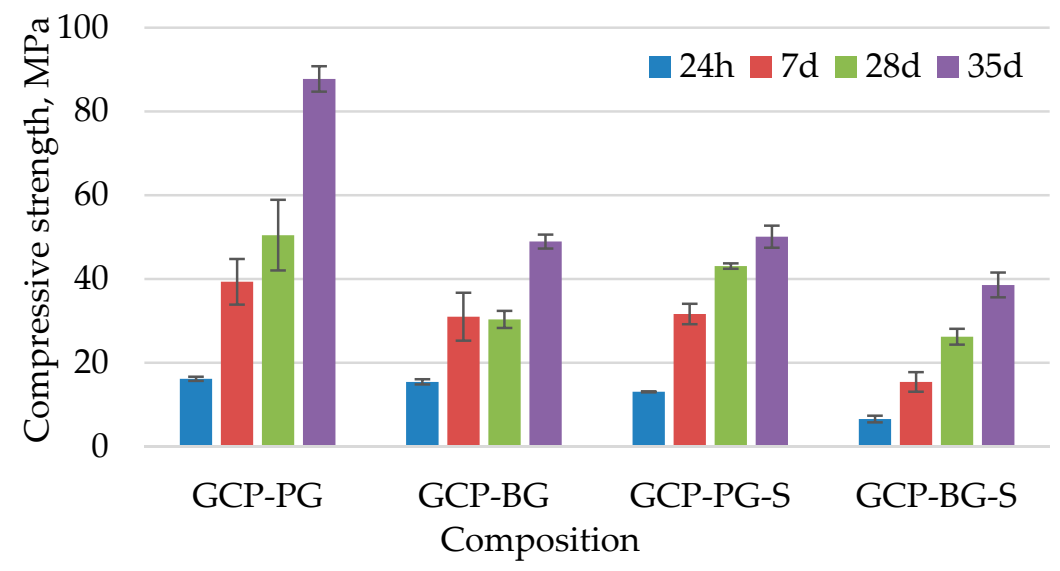

Figure 6. The compressive strength of ternary binder and mortar.

\subsection{Properties of Foamed Ternary System Binder}

The porous ternary system binder was described through its appearance in macro and micro levels. Physical properties such as density, thermal conductivity as well as mechanical properties such as compressive strength and compressive strength softening coefficient regarding water saturation were determined.

\subsubsection{Appearance of Foamed Ternary System Binder}

The macrostructure and microstructure of foamed ternary system binder are given in Figure 7. The material appearance is light grey, similar to Portland cement-based materials. The structure of all samples is monolithic and materials are easy to handle. The macrostructure is highly porous for all samples. The pores are distributed uniformly throughout the sample. The pore macrostructure for samples made with BG has larger pores comparing to samples made with PG. This was also confirmed by the pore measurements with digital microscope. Microstructure is generally homogenous while still different particles can be observed in the matrix. The samples with PG have smaller pores that could be evaluated more precisely in micro-level. Depending on the mixture composition, the increase of binder paste in the same foam amount leads to smaller pores remaining the characteristics coming from gypsum source described before. For GCP-BG-1, macro pores with size in range from 1-4 mm were formed while smaller pores were detected within the large pore walls. The smaller pores were in 
range from $0.2-1.0 \mathrm{~mm}$. GCP-BG-2 had more uniform large pores in a range of $2 \mathrm{~mm}$, while smaller pores were observed in the range from $0.2-0.6 \mathrm{~mm}$. GCP-PG-1 had pores up to $0.7 \mathrm{~mm}$. While most of the pore size was in range from $0.1-0.5 \mathrm{~mm}$. For GCP-PG-2, the structure was similar to GCP-PG-1. The pore size was in range from $0.1-0.6 \mathrm{~mm}$.

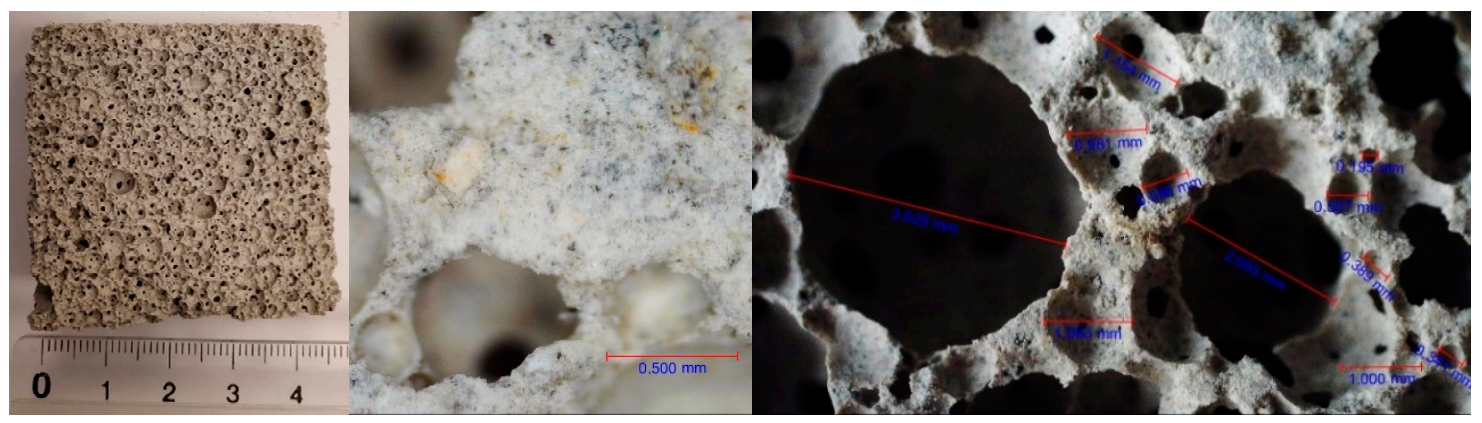

(a)

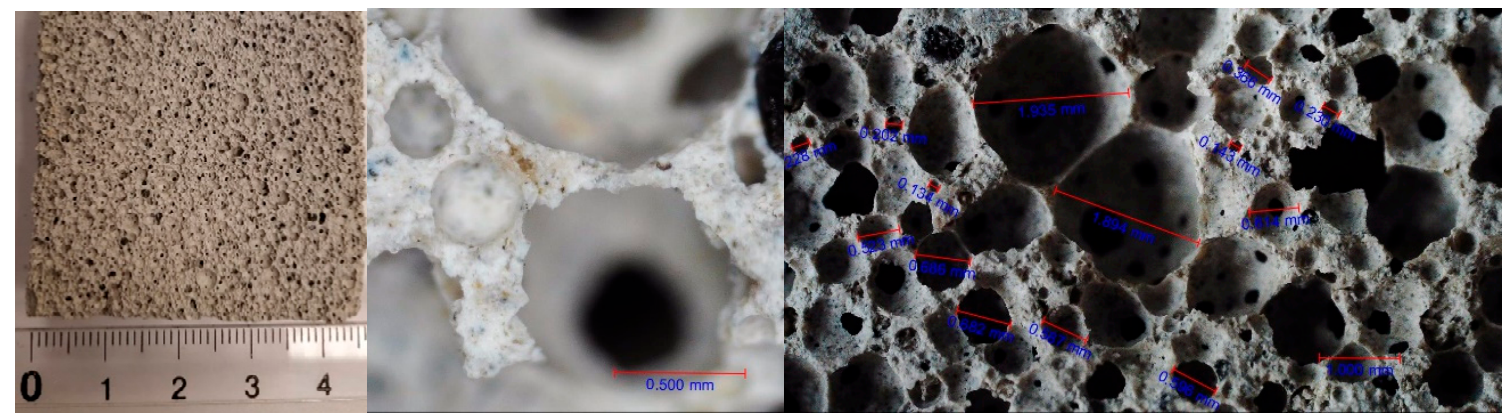

(b)

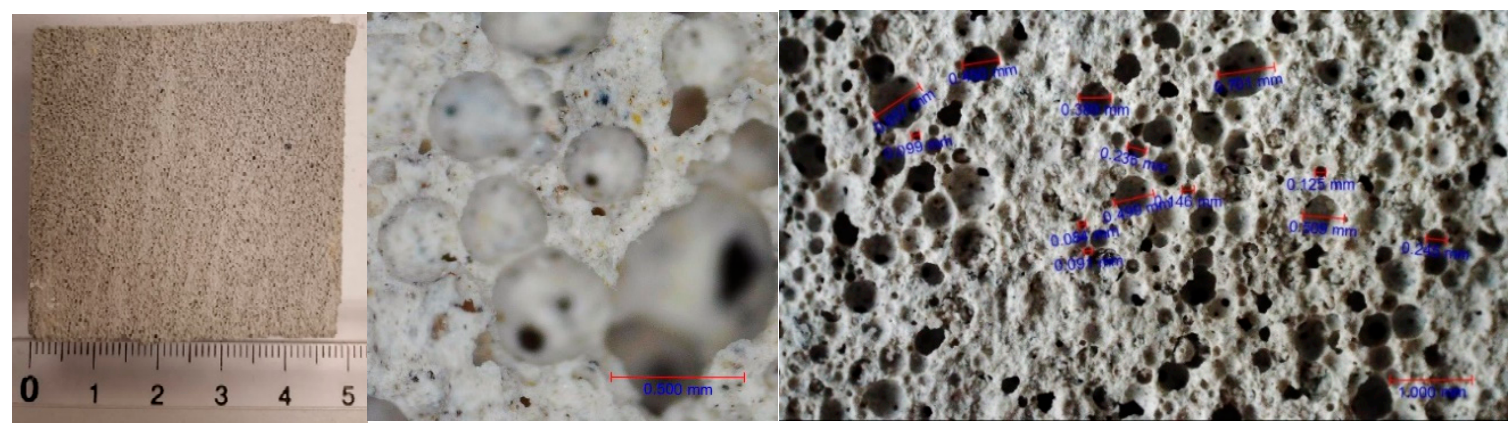

(c)

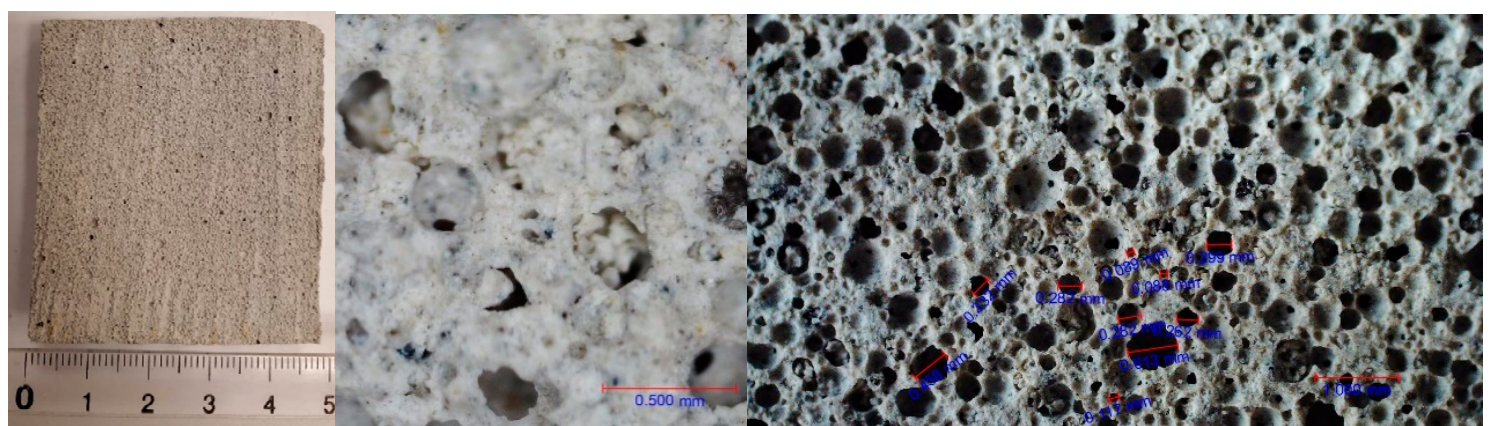

(d)

Figure 7. Macrostructure and microstructure of ternary system binder foams. (a) GCP-BG-1, (b) GCP-BG-2, (c) GCP-PG-1, (d) GCP-PG-2. 
The microstructure of samples observed with SEM is given in Figure 8. The pore hierarchical structure remained the same as previously observed with digital microscope. For mixture GCP-BG, large pores are also visible in SEM. In large magnification, the structure similar to cement-based composites is visible. It has a complex fine-grained structure with the large monolithic structure in smaller magnification. The magnification at 500x reveals the interaction between binder components and different regions, which can be identified.

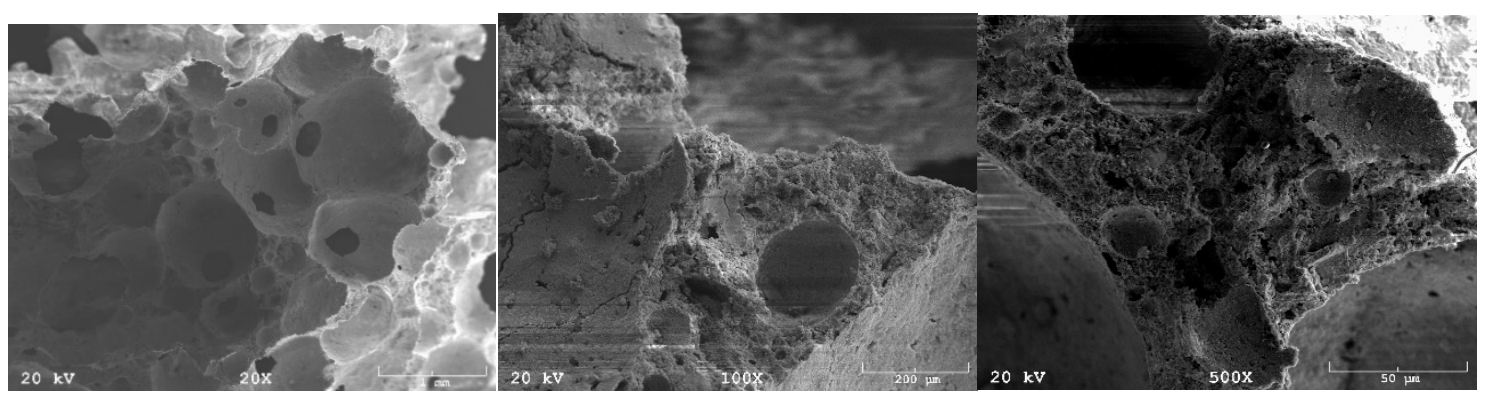

(a)

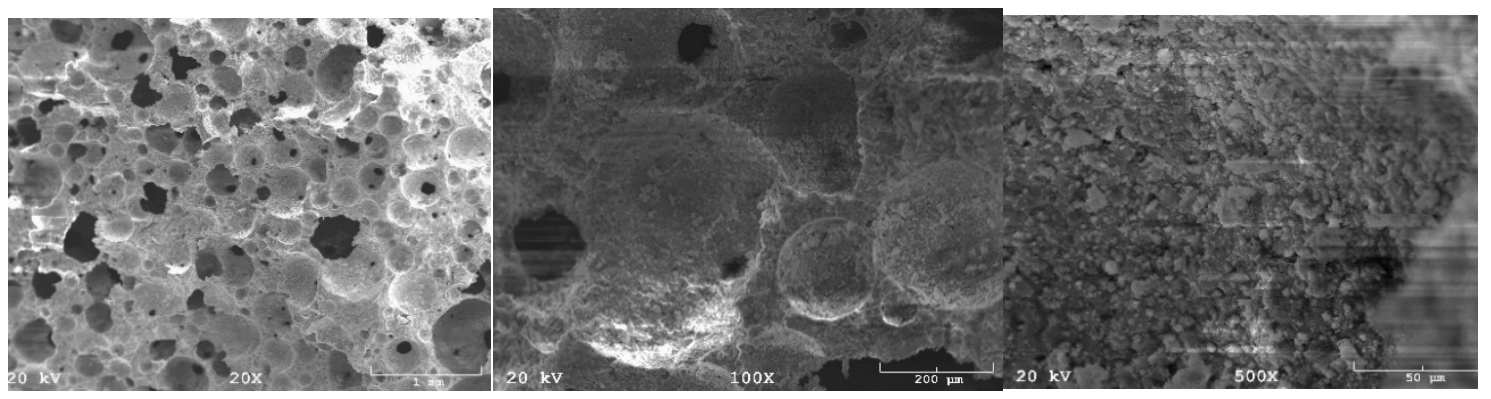

(b)

Figure 8. The micrographs of ternary system binder foam observed with SEM. (a) GCP-BG-1, (b) GCP-PG-1.

\subsubsection{Physical and Mechanical Properties}

The physical properties of ternary system binder foams are given in Table 5. Due to larger pores, the bulk density of GCP-BG foams is lower comparing to GCP-PG foams. The lightweight material with density 368 and $486 \mathrm{~kg} / \mathrm{m}^{3}$ was obtained depending on the amount of paste mixed with foams. GCP-PG foams density increased to 634 and $697 \mathrm{~kg} / \mathrm{m}^{3}$, respectively, which is associated with the smaller pores formed in the production process. The total porosity was higher for GCP-BG, which explains the lower bulk density. The total porosity was 84 and 79 vol. $\%$ for GCP-BG and 72 and $70 \mathrm{wt} \%$ for GCP-PG. Important finding was that open porosity was formed for GCP-BG foams, while for GCP-PG more pores were closed. This is also evidenced by the fact that during the water absorption test the GCP-PG foams remained flowing after total immersion in water (total test time was $72 \mathrm{~h}$ ). The water absorption was 105 and $91 \mathrm{wt}$ \% for GCP-PG foams, while for GCP-PG it was 46 and $39 \mathrm{wt} . \%$, respectively. Density for water-saturated samples increased and was in range from $758-901 \mathrm{~kg} / \mathrm{m}^{3}$.

Table 5. Physical properties of foamed ternary system binder.

\begin{tabular}{|c|c|c|c|c|c|c|c|}
\hline Composition & $\rho_{0}, \mathrm{~kg} / \mathrm{m}^{3}$ & $\rho_{\mathrm{o}}$ wet, $\mathrm{kg} / \mathrm{m}^{3}$ & $\begin{array}{c}\text { Water } \\
\text { Absorption, wt.\% }\end{array}$ & $\begin{array}{l}\text { Open Porosity, } \\
\text { vol. } \%\end{array}$ & $\begin{array}{l}\text { Closed Porosity, } \\
\text { vol. } \%\end{array}$ & $\begin{array}{c}\text { Total Porosity, } \\
\text { vol. } \%\end{array}$ & $\begin{array}{c}\text { Thermal Conductivity, } \\
\lambda, \mathrm{W} / \mathrm{m} \cdot \mathrm{K}\end{array}$ \\
\hline GCP-BG-1 & 368 & 758 & 105 & 39 & 45 & 84 & 0.086 \\
\hline GCP-BG-2 & 486 & 901 & 91 & 43 & 36 & 79 & 0.123 \\
\hline GCP-PG-2 & 697 & 901 & 39 & 25 & 44 & 70 & 0.153 \\
\hline
\end{tabular}

The lowest thermal conductivity of produced specimens was for GCP-BG-1. With the lowest bulk density, the thermal conductivity was as low as $0.086 \mathrm{~W} / \mathrm{m} \cdot \mathrm{K}$. The increase of bulk density for GCP-BG 
increased the thermal conductivity to $0.123 \mathrm{~W} / \mathrm{m} \cdot \mathrm{K}$. Furthermore, GCP-PG-1 had higher bulk density, and due to finer pore size distribution, the thermal conductivity was lower comparing to GCP-BG-2 and it was 0.111 . The GCP-PG-2 had thermal conductivity of $0.153 \mathrm{~W} / \mathrm{m} \cdot \mathrm{K}$.

The compressive strength results of prepared ternary system binder foams are given in Figure 9. The compressive strength of GCP-BG-1 was $0.33 \mathrm{MPa}$ and increased to 1.0 for GCP-BG-2. The increase of compressive strength was observed for GCP-PG. For GCP-PG-1, it was 2.4 MPa and increased to 5.4 MPa for GCP-PG-2. The strength increase is associated with the increase of foam bulk density and with the size of macropores formed during production. For samples made with PG, pores were smaller. Foam samples after water absorption tests were tested for compression to determine softening coefficient of the foams. Since gypsum is not watertight material and in proposed binder it is a major part of the binders' component (50 wt.\%), concerns regarding water tightness were analyzed (Table 6). It was detected that water softening coefficient was from 0.50-0.64. Similar trends were observed with concrete foams before-the compressive strength decreases with the increase of volumetric moisture content for every density ranging from $300-800 \mathrm{~kg} / \mathrm{m}^{3}$, but the softening rate was lower-the compressive strength in the immersed saturation state is about $0.86-0.89$ times of that in the standard curing state [21].

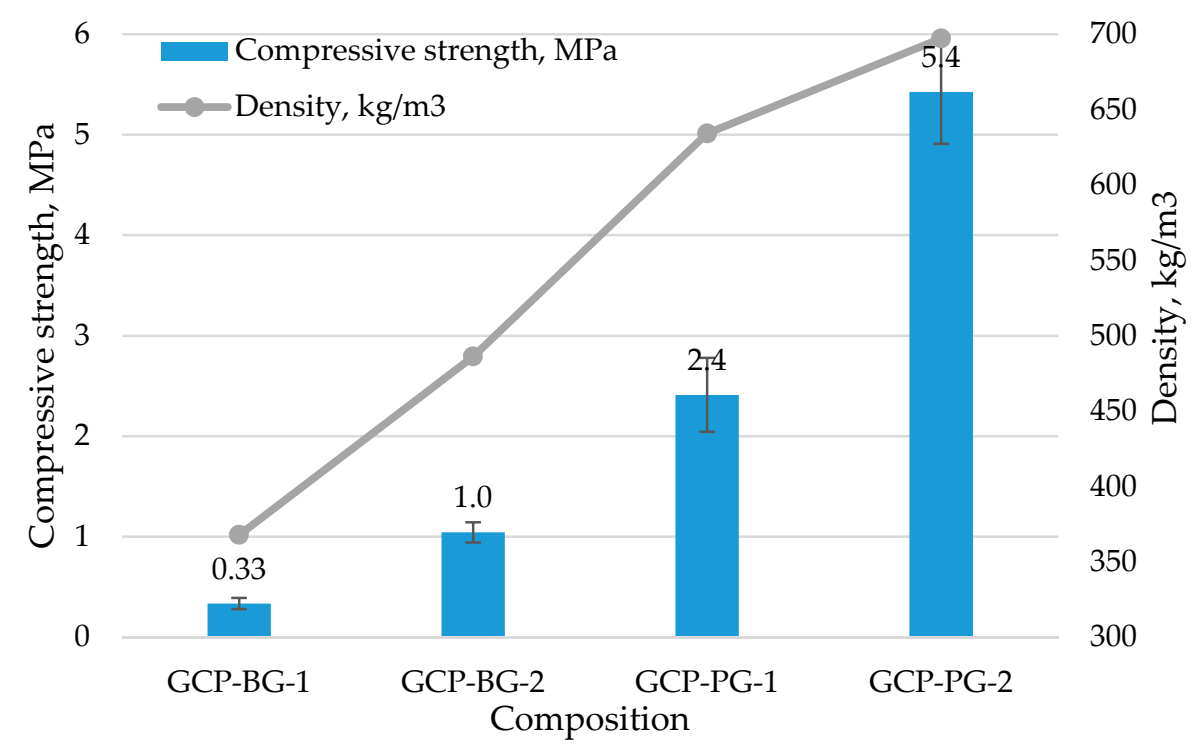

Figure 9. The relation between bulk density and thermal conductivity of foamed ternary system binder.

Table 6. Physical properties of foamed ternary system binder.

\begin{tabular}{cccc}
\hline Composition & Dry Compression Strength, MPa & Saturated Compression Strength, MPa & Softening Coefficient \\
\hline GCP-BG-1 & $0.3 \pm 0.06$ & $0.2 \pm 0.02$ & 0.56 \\
GCP-BG-2 & $1.0 \pm 0.10$ & $0.6 \pm 0.06$ & 0.59 \\
GCP-PG-1 & $2.4 \pm 0.37$ & $1.2 \pm 0.06$ & 0.50 \\
GCP-PG-2 & $5.4 \pm 0.52$ & $3.5 \pm 0.17$ & 0.64 \\
\hline
\end{tabular}

\section{Conclusions}

High-strength ternary system binder was developed containing major part of gypsum, metakaolin, and Portland cement. Valorization option for waste phosphogypsum and metakaolin was offered by incorporating these materials in high-performance cementitious composites and by producing highly porous lightweight foam materials. Proposed binder has technological properties similar to traditional cementitious binders based on Portland cement. The mixture composition with low W/B ratio of 0.34 was developed with the addition of superplasticizer. The set time of binder was adjusted by the help of the set retarder and it is comparable to Portland cement. Impressive compressive strength of up to $88 \mathrm{MPa}$ was reached. The binder proved to be suitable to produce mortar with a strength of up 
to $50 \mathrm{MPa}$. Samples were prepared by a simple methodology that, together with the use of wastes, contributes to improve sustainability of the process. Foamed ternary system binder material with density in range from $368-697 \mathrm{~kg} / \mathrm{m}^{3}$ was obtained with compressive strength from 0.33 to $3.5 \mathrm{MPa}$. Besides technological properties, long-term properties such as durability, shrinkage/swelling should be evaluated, as gypsum with cement can form hazardous compounds such as ettringite, which could lead to loss of integrity of the material.

Author Contributions: Conceptualization, G.B. and D.B.; methodology, G.B. and D.B.; validation, G.B., D.B., and J.Z.; formal analysis, G.B.; investigation, G.B and J.Z.; resources, G.B. and D.B.; data curation, G.B.; writing-original draft preparation, G.B.; writing-review and editing, G.B., J.Z., and D.B.; visualization, G.B. and J.Z.; supervision, G.B. and D.B.; project administration, G.B. and D.B.; funding acquisition, G.B. All authors have read and agreed to the published version of the manuscript.

Funding: This work has been supported by the European Regional Development Fund within the Activity 1.1.1.2 "Post-doctoral Research Aid" of the Specific Aid Objective 1.1.1 "To increase the research and innovative capacity of scientific institutions of Latvia and the ability to attract external financing, investing in human resources and infrastructure" of the Operational Program "Development of sustainable and effective lightweight building materials based on secondary resources" (No. 1.1.1.2/VIAA/1/16/050).

Conflicts of Interest: The authors declare no conflict of interest.

\section{References}

1. Bicer, A.; Kar, F. Thermal and mechanical properties of gypsum plaster mixed with expanded polystyrene and tragacanth. J. Therm. Sci. Eng. Prog. 2017, 1, 59-65. [CrossRef]

2. Lushnikova, N.; Dvorkin, L. Sustainability of gypsum products as a construction material. J. Sustain. Constr. Mater. 2016, 643-681. [CrossRef]

3. British Standards Institution. BS EN 12859:2011, Gypsum Blocks—Definitions, Requirements and Test Methods; BSI: London, UK, 30 April 2011; p. 38. ISBN 9780580710360.

4. Dragomir, A.M.; Lisnic, R.; Prisecaru, T.; Prisecaru, M.M.; Vîjan, C.A.; Nastac, D.C. Study on synthetic gypsum obtained from wet flue gas desulphurisation in thermal power plants. J. Rev. Rom. Mater. Rom. Mater. 2017, 47, 551-556.

5. Tayibi, H.; Choura, M.; López, F.A.; Alguacil, FJ.; López-Delgado, A. Environmental impact and management of phosphogypsum. J. Environ. Manag. 2009, 90, 2377-2386. [CrossRef] [PubMed]

6. Bumanis, G.; Zorica, J.; Bajare, D.; Korjakins, A. Technological properties of phosphogypsum binder obtained from fertilizer production waste. J. Energy Procedia 2018, 147, 301-308. [CrossRef]

7. Zhang, L.; Zhang, A.; Li, K.; Wang, Q.; Han, Y.; Yao, B.; Gao, X.; Feng, L. Research on the pretreatment and mechanical performance of undisturbed phosphogypsum. J. Case Stud. Constr. Mater. 2020, 13, e00400. [CrossRef]

8. Kumar, S. Fly ash-lime-phosphogympsum hollow blocks for walls and partitions. J. Build. Env. 2003, 38, 291-295. [CrossRef]

9. Morsy, M.S.; Rashad, A.M.; Shoukry, H.; Mokhtar, M.M.; El-Khodary, S.A. Development of lime-pozzolan green binder: The influence of anhydrous gypsum and high ambient temperature curing. J. Build. Eng. 2020, 28, 101026. [CrossRef]

10. Huang, Y.; Lin, Z.S. Investigation on phosphogypsum-steel slag-granulated blast-furnace slag-limestone cement. J. Constr. Build. Mater. 2010, 24, 1296-1301. [CrossRef]

11. Zhang, G.; Li, G.; Li, Y. Effects of superplasticizers and retarders on the fluidity and strength of sulphoaluminate cement. J. Constr. Build. Mater. 2016, 126, 44-54. [CrossRef]

12. Akhlaghi, O.; Aytas, T.; Tatli, B.; Sezer, D.; Hodaei, A.; Favier, A.; Scrivener, K.; Menceloglu, Y.Z.; Akbulut, O. Modified poly(carboxylate ether)-based superplasticizer for enhanced flowability of calcined clay-limestone-gypsum blended Portland cement. J. Cem. Concr. Res. 2017, 101, 114-122. [CrossRef]

13. Namsone, E.; Šahmenko, G.; Korjakins, A. Durability Properties of High Performance Foamed Concrete. J. Procedia Eng. 2017, 172, 760-767. [CrossRef]

14. Skujans, J.; Iljins, U.; Ziemelis, I.; Gross, U.; Ositis, N.; Brencis, R.; Veinbergs, A.; Kukuts, O. Experimental research of foam gypsum acoustic absorption and heat flow. J. Chem. Eng. Trans. 2010, 19, 79-84. [CrossRef] 
15. Ma, B.; Jin, Z.; Su, Y.; Lu, W.; Qi, H.; Hu, P. Utilization of hemihydrate phosphogypsum for the preparation of porous sound absorbing material. J Constr. Build. Mater. 2020, 234, 117346. [CrossRef]

16. Nizevičienè, D.; Vaičiukynienè, D.; Michalik, B.; Bonczyk, M.; Vaitkevičius, V.; Jusas, V. The treatment of phosphogypsum with zeolite to use it in binding material. J Constr. Build. Mater. 2018, 180, 134-142. [CrossRef]

17. Bumanis, G.; Vitola, L.; Stipniece, L.; Locs, J.; Korjakins, A.; Bajare, D. Evaluation of Industrial by-products as pozzolans: A road map for use in concrete production. J Case Stud. Constr. Mater. 2020, 13, e00424. [CrossRef]

18. Nguyen, V.H.; Leklou, N.; Aubert, J.E.; Mounanga, P. The effect of natural pozzolan on delayed ettringite formation of the heat-cured mortars. J Constr. Build. Mater. 2013, 48, 479-484. [CrossRef]

19. Bajare, D.; Bumanis, G.; Shakhmenko, G.; Justs, J. High performance and conventional concrete properties affected by ashes obtained from different type of grasses. J Am. Concr. Inst. 2012, 289, 317-330.

20. Žvironaite, J.; Kligys, M.; Pundiene, I.; Pranckevičiene, J. Effect of limestone particles on rheological properties and hardening process of plasticized cement pastes. J Medzg. 2015, 21, 143-148. [CrossRef]

21. Zhao, W.; Su, Q.; Wang, W.; Niu, L.; Liu, T. Experimental study on the effect of water on the properties of cast in situ foamed concrete. J Adv. Mater. Sci. Eng. 2018. [CrossRef]

(C) 2020 by the authors. Licensee MDPI, Basel, Switzerland. This article is an open access article distributed under the terms and conditions of the Creative Commons Attribution (CC BY) license (http://creativecommons.org/licenses/by/4.0/). 